visiting foreign parts. One group was resident in an Israel kibbutz; they visited neighbouring bedouins and were invited to drink goats' milk. The other group were members of an archaeological expedition to Greece, among whom the suspected vehicle was goat and sheep cheese. Br melitensis was isolated from the patient in Israel; which species attacked the patient in Greece is not stated, but an agglutination test gave conclusive evidence of brucellosis. Each of the individuals affected was taking antacids-preparations of magnesium and aluminium hydroxides. Steffen ${ }^{7}$ reviews the published work on achlorhydria as a factor in susceptibility to infection by the alimentary route, and poses the question: "Ought we not to be more reluctant in prescribing antacids to travellers who might expose themselves to the risk of this and other infections?" This seems to be an avoidable risk for travellers to areas where brucellosis or indeed enteric fever is endemic.

The paper by Sliman at p 751 may have an indirect bearing on this subject. It is concerned chiefly with the occurrence of the Guillain-Barré syndrome as a direct sequel of an epidemic of diarrhoea in a town in Jordan where the water supply was polluted by sewage. An added interest is that two other infections were apparently transmitted by the same means; an opportunity of comparing the incidence of three water-borne diseases derived from the same source is unusual. In the exposed population of 30000 the attack rate of diarrhoea was $16.6 \%$, of typhoid fever $1.5 \%$, and of infectious hepatitis $0.6 \%$. The extent of pollution by each of the three agents concerned is, of course, unknown, as is the nature of the agent causing diarrhoea, although dysentery bacilli were found in a few cases. Whatever the agent mainly responsible it should have been one with a high resistance to gastric acid.

${ }^{1}$ Hurst, A F, British Medical fournal, 1934, 2, 665.

2 Garrod, L P, Fournal of Pathology and Bacteriology, 1937, 45, 473.

3 Garrod, L P, St Bartholomew's Hospital Reports, 1939, 72, 145.

${ }^{4}$ Morales-Otero, P, Fournal of Infectious Diseases, 1933, 52, 54.

5 Vanzant, F R, et al, Archives of Internal Medicine, 1932, 49, 345.

${ }^{6}$ Alvarez, W C, et al, American fournal of Digestive Diseases and Nutrition, 1936, 3, 162.

7 Steffen, R, Scandinavian Fournal of Infectious Diseases, 1977, 9, 311.

\section{Assessing clinical practice in genitourinary medicine}

No one disputes that regular assessment of diagnostic methods and results of treatment is essential to the maintenance of high standards of medical care; there is less agreement about ways of collecting information about clinical practice. Both the Hospital Inpatient Enquiry (HIPE) and Hospital Activity Analysis (HAA) provide data that are readily available to clinicians and hospital administrators. Unfortunately, with both systems doubts about the accuracy of the data and delays in their collection have reduced their value to hospital doctors. The alternative is for data to be obtained independently by individuals or groups of clinicians. This type of medical assessment, however, may be antipathetic, with anxieties about being watched by "big brother" and fears of eventual loss of clinical freedom; thus Rhodes ${ }^{1}$ has pointed out that "audit must be done by doctors who want it, not imposed from outside."

Venereologists have been pioneers in assessment in Britain. They set about the process of self-appraisal by three related mechanisms. Firstly, the British Co-operative Clinical Group -a voluntary association of clinicians-has been responsible for surveys and data collection. The group's findings have been disseminated and discussed by the Medical Society for the Study of Venereal Diseases and within the British fournal of Venereal Diseases, the only specialist journal dealing exclusively with sexually transmitted diseases.

The crucial question is whether the venereologists' approach has made any difference to their clinical performance: what changes have occurred as a result of the studies? In 1968 the British Co-operative Clinical Group ${ }^{2}$ looked at the management of patients with gonorrhoea in Britain. Comparison can now be made with a more extensive study carried out ten years later by Adler, ${ }^{3-4}$ working at the Middlesex Hospital, into the diagnosis, treatment, and notification of the disease.

One change since 1968 has been an improvement in the number of hours that clinics are open to the public: whereas ten years ago $71^{\circ}$, of clinics were open for less than 10 hours per week, this has now been reduced to $53 \%$. The microbiological diagnosis of gonorrhoea may be difficult, especially in women; 10 years ago when the possibility needed to be excluded both Gram-stained smears and cultures were done on women in $96 \%$ of clinics but on men in only $59 \%$. By 1978 this proportion had risen to $81 \%$. In 1968 consultants in $65 \%$ of the clinics used transport media, as opposed to direct plating, but many were dissatisfied with the results. No doubt in consequence of these doubts the present survey reported that physicians in only $49 \%$ of clinics were using transport media.

These are only some of the changes in the diagnosis of gonorrhoea in the past decade. Most have resulted from the publication and availability of the data collected in the original survey in 1968. But even though there have been improvements it would be naive to suppose that there is not room for many more; Adler has identified some of these. For example, his survey showed that not all physicians took routine urethral specimens from heterosexual and active homosexual men who presented for a check-up or were gonorrhoea contacts. In view of recent reports of asymptomatic gonorrhoea in men this approach is unsatisfactory and may result in missed cases. ${ }^{5-7}$ In some clinics doctors did not carry out the optimal number of tests to exclude gonorrhoea in women, whereas others carried out more tests than required. ${ }^{8-9}$

Regular reappraisal of diagnostic and treatment methods should improve standards in any discipline; consultant venereologists have shown how this can be arranged. And since genitourinary medicine is in the forefront of this type of evaluation and scientific approach in Britain, this enthusiasm could help place the specialty on a new footing and make it more attractive to those considering it as a career.

\footnotetext{
${ }^{1}$ Rhodes, P, British Medical fournal, 1974, 4, 278.

${ }^{2}$ British Co-operative Clinical Group, British fournal of Vencreal Diseases, $1971,47,17$.

${ }^{3}$ Adler, M W, British Fournal of Venereal Diseases, 1978, 54, 10.

4 Adler, M W, British Fournal of Venereal Diseases, 1978, 54, 15.

5 Thatcher, R W, et al, Fournal of the American Medical Association, 1969, 210,315 .

${ }^{6}$ Portnoy, J, et al, Canadian Medical Association fournal, 1974, 110, 169.

' Handsfield, $\mathrm{H} \mathrm{H}$, et al, New England Fournal of Medicine, 1974, 290, 117. ${ }^{3}$ Chipperfield, E J, and Catterall, R D, British fournal of Venereal Diseases, 1976, 52, 36.

${ }^{9}$ Evans, B A, British fournal of Venereal Diseases, 1976, 52, 40.
}

We regret that in the leading article "To sign or not to sign ?" (11 March, p 598) we gave the wrong title for the book by Woodford, F P, and O'Connor, M. It should have been Editing Scientific Books and Fournals. 